\title{
LETHAL TEMPERATURES OF INDIAN WEST-PACIFIC AND ATLANTIC EAST-PACIFIC FIDDLER CRABS
}

\author{
Jimenez, P.J. ${ }^{1}$; Quadros, A.F. ${ }^{1}$; Costa, T.M. ${ }^{2}$ \& Cannicci, S. ${ }^{1}$ \\ ${ }^{1}$ The University of Hong Kong, The Swire Institute of Marine Science, Mangrove Ecology and Evolution Laboratory. \\ ${ }^{2}$ São Paulo State University, São Paulo Coastal Campus, Laboratory of Ecology and Behaviour.
}

*Corresponding author: pjimenez@hku.hk

The aim of this study was to compare the lethal temperatures (LT) of fiddler crabs living in similar habitats from two distinct clades, the Indian West-Pacific (IWP) and the Atlantic East-Pacific (AEP). In the AEP, the studied fiddler crabs were: Leptuca thayeri, from low shores (LS), L. leptodactyla, at exposed areas in the mid shore (MS), and L. uruguayensis, at shadowed areas in the high-shores (HS). Gelasimus borealis (LS), Austruca lactea (MS) and Paraleptuca splendida (HS) were analysed in the IWP. The AEP crabs were collected at Itaguaré River Mouth, São Paulo, Brazil; and the IWP crabs were collected at Tung Chung, Hong Kong, China. The temperatures experienced by the model species were recorded by thermo-loggers deployed at the sampling sites. The LT was based on the endpoint of the cardiac function (EPT), obtained by testing twenty specimens of each species to a thermal ramp, starting at $25^{\circ} \mathrm{C}$ and increasing $1^{\circ} \mathrm{C}$ at each $20 \mathrm{~m}$, recording the heartbeats by an infra-red sensor attached to the crabs' carapace connected to an oscilloscope. The data was compared by an Analysis of Variance (ANOVA) with region (IWP and AEP) and shore height the species occupy (LS, MS and HS) as fixed factors and LT as dependent variable. The temperatures at the Itaguaré river mouth ranged from $19.6^{\circ} \mathrm{C}$ to $36.8^{\circ} \mathrm{C}$ at the LS, $20.1^{\circ} \mathrm{C}$ to $45.3^{\circ} \mathrm{C}$ at the MS, and $20.7^{\circ} \mathrm{C}$ to $39.7^{\circ} \mathrm{C}$ at the HS. At Tung Chung, the temperatures ranged from $24.4^{\circ} \mathrm{C}$ to $44.7^{\circ} \mathrm{C}$ at the LS-MS (similar characteristics between the sites) and $25.1^{\circ} \mathrm{C}$ to $37.6^{\circ} \mathrm{C}$ at the HS. The LT where: $42.6 \pm 1.4$ for $L$. thayeri, $42.5 \pm 1.7$ for L. leptodactyla, $40.7 \pm 1.7$ for L. uruguayensis, $42.4 \pm 1.4^{\circ} \mathrm{C}$ for G. borealis, $43.7 \pm 0.9^{\circ} \mathrm{C}$ for $A$. lactea and $42.9 \pm 1.2$ for $P$. splendida. The interaction between Shore height and region have a significant effect on the LT of the crabs (ANOVA, $F_{(2,114)}=7.947$, MSE=1.991, $p<0.001$ ), with the HS specie from the AEP, L. uruguayensis, presenting a lower LT compared to the other species of the clade (Tukey HSD, p <0.05), while in the IWP the LT does not significantly differ among the model species. The different responses in the LT among species of the two clades can be related to the patterns of distribution and adaptation of the species inside the clades. L. uruguayensis, showed to be adapted to the colder weather in higher latitudes to the south, being the southernmost species of fiddler crab from the Americas, while the IWP species have an overlapping distribution towards lower latitudes.

Keywords: Gelasiminae, heart function, lethal temperatures, physiology. 